\title{
PENGARUH GLUTAMIN \& GLUKOSA UNHIDRAT PADA JUMLAH LIMFOSIT TIKUS MODEL KURANG ENERGI PROTEIN
}

\author{
Septa Katmawanti \\ Fakultas Ilmu Keolahragaan Universitas Negeri Malang \\ Bambang Wirdjadmaji \\ Annis Catur Adi \\ Universitas Airlangga \\ e-mail: septakatma@gmail.com
}

\begin{abstract}
Protein-energy malnutrition condition causes lymphocytes number to decrease which then lead to body's cellular immune system disorders, the condition where patient is more vulnerable to infection. Number of lymphocytes in the body is dependent to some factors, some of them are anti-oxidant, amino acid glutamine and glucose. The aim of his research is to study the effect of L-glutamine and glucose unhidrate administration in rat model of protein-energy malnutrition to the increase of lymphocytes number in the blood. This is an experimental study with Completely Random Design. Sample is malnutrition induced with parched rice for 15 days $(n=20)$. Then some samples are examined to figure out the lymphocytes number after the rate model experience lack of energy and protein. Sample is then divided into four treatment groups, they are: group with normal diet (control), normal diet + L-glutamine, normal diet + glucose unhidrate, and normal diet + L-glutamine + glucose unhidrate. Lymphocytes content is measured again after 10 days. The result of the study shows that number of lymphocytes increase significantly $(\mathrm{P}<0.05)$ in the four treatment groups after the intervention compared with number of lymphocytes in the malnutrition induced group. Statistical analysis of the four groups with L-glutamine and glucose unhidrate administered shows significant difference each other $(p<0.05)$. These observations imply that the glutamin and gluocose unhidrat has an effect to the increase of lymphocytes number in the blood.
\end{abstract}

Keywords: Protein-Energy Malnutrition (PEM), lymphocyte, l-glutamine, glucose unhidrate

Abstrak: Kondisi KEP menyebabkan penurunan jumlah limfosit yang mengakibatkan gangguan sistem imun seluler tubuh, sehingga penderita menjadi lebih rentan terhadap infeksi. Jumlah sel limfosit pada tubuh dipengaruhi oleh beberapa faktor antara lain keberadaan antioksidan, asam amino glutamin dan glukosa. Penelitian ini bertujuan untuk mengetahui pengaruh pemberian glutamin dan glukosa unhidrat pada tikus model KEP terhadap kenaikan jumlah limfosit darah. Studi ekperimental menggunakan metode Rancang Acak Lengkap. Sampel diinduksi malnutrisi dengan nasi aking (karak) selama

15 hari $(\mathrm{n}=20)$. Kemudian subsampel diperiksa untuk mengetahui jumlah limfosit setelah tikus mengalami kekurangan energi dan protein. Sampel kemudian dibagi menjadi empat kelompok perlakuan, yaitu kelompok dengan diet normal (kontrol), diet normal + glutamin, diet normal + glukosa unhidrat, dan diet normal + glutamin + glukosa unhidrat. Kadar limfosit diukur kembali setelah 10 hari. Hasil penelitian ini menunjukkan bahwa setelah dilakukan intervensi terdapat kenaikan jumlah limfosit secara bermakna $(\mathrm{P}<0,05)$ pada keempat kelompok perlakuan dibandingkan dengan jumlah limfosit pada kelompok induksi malnutrisi. Analisis secara statistik pada keempat kelompok yang diberikan intervensi Glutamin dan glukosa unhidrat menunjukkan bahwa terdapat perbedaan yang bermakna satu sama lain $(p<0,05)$.

Kata kunci: Kekurangan Energi Protein (KEP), limfosit, glutamin, glukosa unhidrat 
Di Indonesia terdapat 4 masalah gizi utama yang memerlukan perhatian khusus untuk segera ditangani. Masalah gizi tersebut antara lain Kurang Energi Protein (KEP), Gangguan Akibat Kurang Yodium (GAKY), Anemia dan Kurang Vitamin A (KVA). KEP merupakan salah satu masalah gizi kurang akibat konsumsi makanan yang tidak cukup mengandung energi dan protein serta karena gangguan kesehatan. Berdasarkan hasil Riset Kesehatan Dasar tahun 2010, secara nasional terjadi penurunan prevalensi gizi kurang (berat badan menurut umur) pada balita dari $18,4 \%$ pada tahun 2007 menjadi 17,9\% persen pada tahun 2010. Penurunan juga terjadi pada prevalensi gizi buruk pada tahun 2007 yaitu $5,4 \%$ menjadi $4,9 \%$ pada tahun 2010 . Target MDGs untuk indikator prevalensi kekurangan gizi pada anak sebesar 15,5\% sedangkan hasil Riset Kesehatan Dasar tahun 2010 menunjukkan bahwa terjadi penurunan tingkat prevalensi kekurangan gizi dari $18,4 \%$ (pada tahun 2007) menjadi $17,9 \%$ pada tahun 2010. Agar target kekurangan gizi 2015 sebesar 15,5\% diperkirakan dapat tercapai maka percepatan perlu dilakukan untuk indikator prevalensi kekurangan gizi sebesar $15,5 \%$ dapat segera tercapai secara nasional (Depkes,2000). Salah satu fungsi utama protein untuk

meningkatkan pertahanan. Selain merupakan komponen dasar dari sistem imun itu sendiri, protein juga memegang peranan penting terhadap pematangan sistem imun (Mezenes,2003).

Glutamin memiliki kemampuan untuk meningkatkan imunitas di dalam tubuh. Mekanisme glutamin untuk meningkatkan fungsi imunitas adalah dengan cara menstimulasi produksi glutathione (GSH) di beberapa jaringan dan melindungi tempat penyimpanan

glutamine otot. GSH merupakan pusat dari sistem pertahanan tubuh terhadap antioksidan yang mengatur semua aspek fungsi imun. Selain itu, glutamin juga berfungsi dalam proses proliferasi limfosit dengan cara membentuk replikasi DNA dan RNA di dalam sel (Lee WJ, Hawkins RA\&Vina
JR,1998). Penelitian pada hewan coba yang diberikan diet yang terdiri dari 40 gram glutamin selama 10 hari memberikan respon imun yang signifikan mencegah influenza, dipteri, dan tetanus (Lee WJ, Hawkins RA\& Vina JR,1998).

Setiap sel dan jaringan yang terdapat di dalam tubuh makhluk hidup membutuhkan glukosa untuk proses metabolisme. Glukosa adalah zat yang penting dan dibutuhkan untuk survival, ukuran, aktivasi sel dan juga untuk produksi cytokine. Glukosa memberikan energi yang dibutuhkan bagi limfosit-T untuk proses metabolik menghasilkan ATP (Maclver J, Nancie\&Jacobs R Sarah, 2008). Penelitian yang dilakukan oleh Migeul et al, menunjukkan bahwa formula gabungan antara glutamin dan glukosa yang diberikan pada hewan coba selama 15 hari dapat meningkatkan jumlah sellimfosit-T hewan coba tersebut (Migeul P, Beeh KM, Schlaak JF\&Buhl $R, 2001)$. Pada penelitian yang dilakukan oleh Curi pada tahun 2009 menunjukkan bahwa pemberian glutamin dan glukosa pada formula enteral menurunkan kejadian sepsis pada pasien pasca operasi (Curi et al, 2009).

Masalah kurang energi protein (KEP), hingga saat ini masih merupakan masalah kesehatan masyarakat, walaupun usaha perbaikan gizi keluarga oleh lembaga pemerintah maupun nonpemerintah sudah banyak dilaksanakan. Pembuatan makanan alternatif untuk percepatan penanggulangan KEP telah banyak dilakukan dan dalam hal ini peneliti melakukan penelitian pendahuluan terhadap efektifitas glutamin dan glukosa terhadap jumlah limfosit hewan coba dalam kondisi kurang energi protein.

\section{METODE \\ Bahan}

Tikus strain wistar Rattus novergicus yang diambil secara acak, dengan kriteria sebagai berikut: (1) Jenis kelamin jantan dan aktif; (2) Umur 12 minggu; (3) Berat badan 100-200 gram; (4) Warna bulu putih; (5) Diadaptasikan selama 3 hari di lingkungan laboratorium 
pemberian ransum tikus berdasarkan pada jumlah kebutuhan pakan tikus per harinya yaitu 30 gram per hari, memakaipakan BR-1. Diet KEP yang digunakan adalah menggunakan karak (nasiaking) dengan pemberian per hari sebanyak 25-30 gram (Curi et al, 2009). Penghitungan diet pada saat perlakuan menggunakan prinsip diet isokalori dan isoprotein. Pemberian diet didasarkan atas kebutuhan protein tikus serta disesuaikan dengan kemampuan tikus untuk menghabiskan diet. Diperkirakan dalam sehari kapasitas makan tikus adalah sebanyak $\pm 30 \mathrm{~g}$, maka diet diberikan dengan jumlah kurang lebih sebanyak $\pm 30 \mathrm{~g}$.

Pemberian suplemen glutamin

disesuaikan dengan penelitian Newsholme (2001) yang menyatakan bahwa tikus yang diberikan glutamin sebanyak 20 gram dalam kurun waktu 10 hari memberikan efek dapat meningkatkan proliferasi limfosit, sehingga untuk penelitian ini jumlah suplementasi glutamin per hari adalah 2 gram. Penambahan glukosa sesuai dengan penelitian Curi et al (2010)

menunjukkan bahwa perbandingan glutamin dan glukosa yang diberikan pada hewan coba adalah dengan pebandingan 1:1, sehingga penambahan glukosa sebanyak 2 gram. Pada penelitian Michael (2008) menunjukkan bahwa pengenceran yang harus dilakukan untuk gabungan suplementasi glutamin dan glukosa adalah $10 \mathrm{cc}$.

\section{Tikus Model}

Penelitian menggunakan sampel tikus karena tikus adalah hewan coba yang paling mudah digunakan dan kedekatan dengan manusia antara lain: mamalia, pemakan segala (omnivora), mudah berkembang biak dan mudah dalam perawatannya, dan mempunyai metabolisme mirip manusia (Widiarti, 1995). Selain itu tikus merupakan spesies kecil yang murah (Nurdiana, dkk, 1998). Penelitian ini menggunakan tikus putih Rattus novergicus strain Wistar dengan kelompok 1 sebagai kontrol positif (normal), kelompok 2 yaitu tikus kurang energi protein dengan penambahan glutamin, kelompok 3 yaitu tikus kurang energi protein dengan penambahan glukosa, kelompok 4 yaitu tikus kurang energi protein dengan penambahan glutamin dan glukosa. Sebanyak 20 sampel ditambah dengan 4 cadangan tikus pada setiap perlakuan diteliti homogen dalam jenis kelamin, umur dan berat badan. Untuk meningkatkan validitas internal, saat pembagian sampel menjadi kelompok dilakukan dengan alokasi random (random assignment) yang menggunakan statistik inferensial untuk mencapai tujuan penelitian.

\section{Pengumpulan Data}

Data yang dikumpulkan meliputi:

1. Data Berat Badan yang diperoleh dari hasil penimbangan berat badan tikus menggunakan timbangan merk Sartorius Melter dengan ketelitian $0,1 \mathrm{Kg}$ tiap minggu sekali

2. Data asupan makanan perhari dihitung dengan menimbang sisa makanan yang diberikan pada

hewan coba setiap harinya menggunakan timbangan merk Sartorius Melter dengan ketelitian $0,1 \mathrm{Kg}$

3. Jumlah sel T- limfosit dan Albumin darah. Teknik pengukuran jumlah limfosit didahului dengan pengambilan darah dengan jarum suntik (disposable syringe) lewat vena abdominalis. Setelah itu

dilakukan penghitungan di Laboratorium Poliklinik Universitas Brawijaya Malang menggunakan metode Cobas Micros

\section{Analisis Data}

Hasil penilaian ada tidaknya perubahan pada kadar limfosit didapatkan data rata-rata kadar limfosit darah hewan coba pada masing-masing kelompok, selain itu dianalisis pula data-data fisik klinis berupa berat badan, kadar albumin dan asupan makanan harian, untuk mengetahui apakah sebaran variabel diatas berdistribusi normal maka dilakukan Uji Formal dengan test of normality dari Kolmogorov-Smirnov dan 
Saphiro-Wilk Analisa yang akan digunakan adalah parametric test yaitu uji One Way ANOVA (Analysis of Variance). Uji ini adalah suatu uji statistik inferensial parametrik yang memungkinkan para peneliti dapat menguji apakah dua atau lebih mean dari kelompok-kelompok itu berbeda atau tidak dan menguji apakah varian populasi sama atau tidak. Jika ada perbedaan dilanjutkan dengan uji Post Hoc Tuckey Test untuk melihat perbedaan dari tiap kelompok. Pengujian statistik dilakukan dengan menggunakan kepercayaan $95 \%$. Dalam penelitian ini analisis dengan Independent Sampel $T$ Test digunakan untuk menguji signifikansi beda rata-rata dua kelompok yaitu variabel perlakuan. Uji korelasi Pearson digunakan untuk mengetahui hubungan antara dua variabel, sebagai alat bantu komputerisasi data, peneliti menggunakan program komputer (software).

\section{HASIL}

Jumlah limfosit dalam darah dihitung pada masa induksi diet KEP untuk mengetahui terjadinya perubahan jumlah limfosit sampel penelitian setelah sampel mengalami kondisi malnutrisi energi dan protein. Sampel diambil serum darah yang berasal dari ekor untuk dihitung jumlah limfositnya setelah diberikan induksi diet KEP (Kekurangan Energi Protein), setelah serum darah diambil, sampel penelitian kemudian dirandomisasi dan dilakukan penyesuaian terhadap jenis intervensi yang akan dilakukan. Pada saat akhir masa intervensi, jumlah limfosit dihitung pada semua sampel di keempat kelompok perlakuan dan untuk mengetahui apakah ada perbedaan jumlah limfosit saat induksi KEP (Kekurangan Energi Protein) dan setelah diberikan intervensi, untuk melihat ada tidaknya perbedaan pada masing-masing kelompok perlakuan dilakukan uji statistik dengan menggunakan metode one way Anovaserta dilanjutkan dengan menggunakan uji post Hoc Tuckey. Pada tabel 5.12 berikut ini hasil perhitungan rata-rata jumlah limfosit pada masa induksi diet KEP (Kekurangan Energi Protein) dan setelah sampel diberikan intervensi.

Hasil uji statistik didapatkan bahwa berat badan sampel pada semua kelompok perlakuan tidak menunjukkan perbedaan secara bermakna dengan nilai $\mathrm{p}=0,165(\mathrm{P}>0,05)$. Pada tabel 1 berikut ini merupakan rerata jumlah limfosit sampel penelitian setelah induksi diet KEP

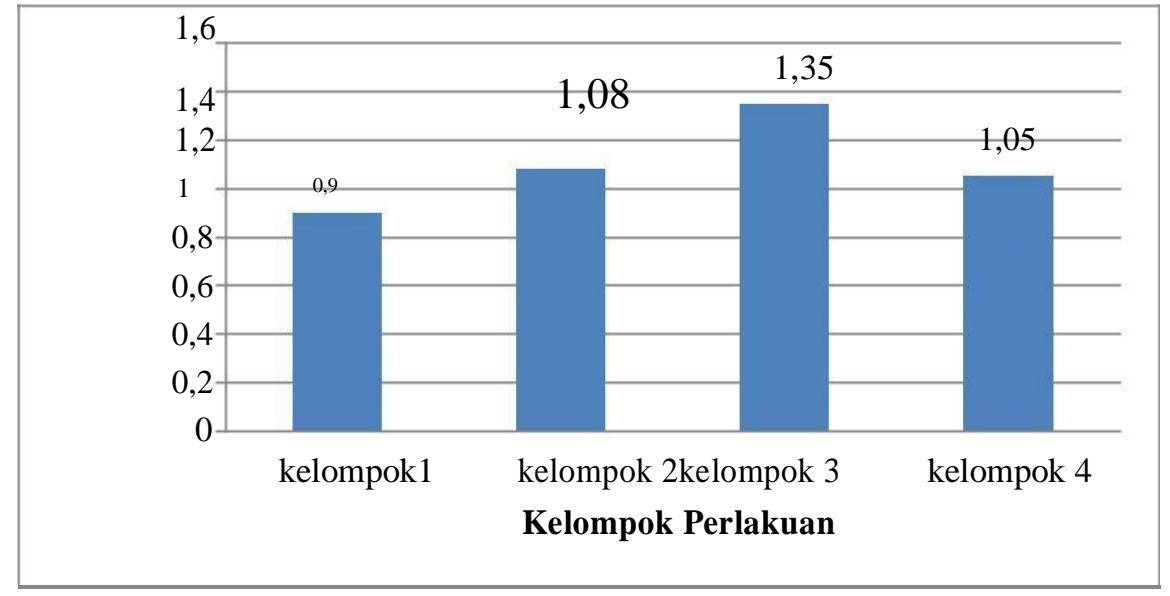

Gambar 1 Rerata Jumlah Kadar Limfosit Setelah Induksi Diet KEP

\section{JumlahLimfosit Sampel}

Uji statistik One Way Anova yang dilakukan dapat mengetahui bahwa setelah dilakukan intervensi terdapat kenaikan jumlah limfosit secara bermakna dengan nilai $\mathrm{p}=0,000(\alpha<0,05)$ 
pada keempat kelompok perlakuan dibandingkan dengan jumlah limfosit pada kelompok diet Kekurangan Energi Protein. Kenaikan tertinggi terjadi pada kelompok perlakuan pemberian LGlutamin+Glukosa Unhidrat (16,98 x
$10^{3}$ ), sedangkan kenaikan terendah terdapat pada kelompok diet normal tanpa pemberian perlakuan $\left(5,51 \times 10^{3}\right)$, pada Gambar 2 berikut ini merupakan rerata jumlah limfosit setelah diberikan intervensi.

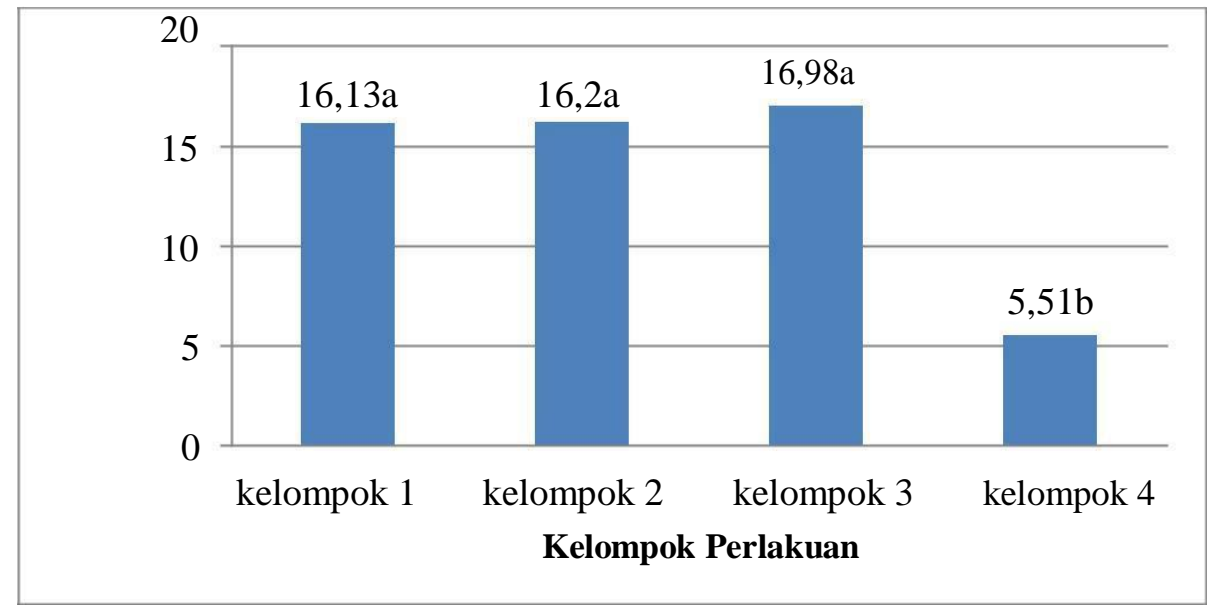

Gambar 2 Rerata Jumlah Limfosit Setelah Diberikan Intervensi

Analisis secara statistik pada keempat kelompok yang diberikan intervensi menunjukkan bahwa terdapat perbedaan yang bermakna satu sama lain (p>0,05). Metode post Hoc Tukey menunjukkan bahwa pada kelompok diet normal tanpa perlakuan memiliki perbedaan yang bermakna terhadap ketiga kelompok yang lain $(p>0,05)$. Sedangkan pada kelompok perlakuan pemberian L-Glutamin menunjukkan

bahwa tidak terdapat perbedaan bermakna dengan kelompok perlakuan glukosa unhidrat dan kelompok perlakuan pemberian Lglutamin+glukosa unhidrat.

Analisis terhadap hubungan jumlah limfosit sebelum dan sesudah diberikan perlakuan dilakukan dengan uji Paired $T$ Test dan didapatkan hasil $\mathrm{p}=0,000(\alpha=$ 0,05). Hal ini bermakna bahwa pemberian L-Glutamin dan glukosa unhidrat memiliki pengaruh yang nyata terhadap peningkatan jumlah limfosit darah sampel penelitian yang diberikan induksi diet Kurang Energi Protein (KEP).

Analisis statistik uji korelasi digunakan mengetahui hubungan antara pemberian intervensi berupa L-Glutamin dan glukosa unhidrat. Tujuan dari uji korelasi adalah untuk mengetahui apakah terdapat hubungan antara variabel penambahan perlakuan L-Glutamin dan Glukosa Unhidrat terhadap jumlah limfosit darah tikus putih. Hasil uji korelasi menunjukkan adanya hubungan yang kuat sebesar 0,678 dengan tingkat signifikansi sebesar $0,000(\mathrm{p}<0,05)$.

Hasil korelasi menunjukkan hubungan yang linier yang berarti jika penambahan L-Glutamin dan glukosa unhidrat semakin besar maka akan semakin besar pula jumlah limfosit darah sampel penelitian

\section{PEMBAHASAN}

Hasil perhitungan rerata jumlah limfosit sebelum diberikan intervensi menunjukkan bahwa kadar limfosit mengalami penurunan pada semua perlakuan dengan nilai $p=0,308 \quad(\alpha>0,05)$ yang berarti tidak berbeda secara bermakna, sedangkan jumlah limfosit

normal adalah 2-4 $\times 10^{3}$. Pemberian intervensi L-Glutamin dan Glukosa unhidrat menyebabkan kenaikan jumlah limfosit pada semua kelompok perlakuan. 
Hasil pengujian statistik jumlah limfosit pada tikus wistar kelompok diet normal dengan penambahan L-Glutamin

menunjukkan rata-rata $16,13 \pm 3,57 \times 10^{3}$. Pada kelompok diet normal dengan

penambahan glukosa unhidrat menunjukkan rata-rata jumlah limfosit

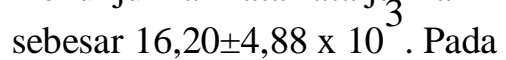

kelompok diet normal dengan penambahan L-Glutamin+glukosa unhidrat menghasilkan rata-rata jumlah limfosit sebesar $16,98 \pm 4,30 \times 10^{3}$. Hasil rata-rata jumlah limfosit terendah pada kelompok diet normal tanpa penambahan perlakuan 3 (kontrol) sebesar $5,51 \pm 0,29 \times 10^{3}$.

Kenaikan tertinggi terjadi pada kelompok diet normal dengan penambahan perlakuan LGlutamin+Glukosa unhidrat dengan rerata jumlah limfosit adalah sebesar

$16,98 \times 10^{3}$ Kenaikan tertinggi kedua adalah pada kelompok perlakuan diet normal dengan penambahan glukosa unhidrat. Penghitungan secara statistik dengan metode one way Anova

menunjukkan terdapat perbedaan bermakna antara rerata jumlah limfosit pada keempat kelompok perlakuan $p=0,01(\alpha<0,05)$. Rerata kelompok

perlakuan diet normal dengan penambahan L-Glutamin dibanding dengan kelompok perlakuan diet normal dengan penambahan glukosa unhidrat tidak memiliki perbedaan yang bermakna dengan nilai $p=1,00(\alpha>0,05)$.

Rerata kelompok perlakuan diet normal dengan penambahan L-Glutamin dibanding dengan kelompok perlakuan diet normal dengan penambahan L-

Glutamin+glukosa unhidrat tidak memiliki perbedaan yang bermakna

dengan nilai $p=0,982 \quad(\alpha>0,05)$, sedangkan rerata kelompok perlakuan diet normal dengan penambahan glukosa unhidrat dibandingkan kelompok perlakuan diet normal dengan penambahan L-Glutamin+glukosa unhidrat tidak memiliki perbedaan yang bermakna dengan nilai $p=0,986(\alpha>0,05)$.

Hasil analisis statistik mengenai perbandingan limfosit pada saat sebelum diberikan perlakuan dengan pada saat setelah selesai pemberian perlakuan menunjukkan perbedaan yang bermakna $\mathrm{p}=0,000(\alpha<0,05)$. Hal ini menunjukkan bahwa intervensi berhasil meningkatkan jumlah limfosit sampel penelitian yang mengalami kondisi kekurangan energi protein (KEP).

Pembentukan limfosit dimulai dari diferensiasi stem sel di tulang belakang, dari sum-sum tulang, limfosit kemudian berdiferensiasi menjadi 2 jenis yaitu limfosit B dan limfosit T. Limfosit B kemudian menuju limfa, sedangkan limfosit $\mathrm{T}$ menuju kelenjar thymus. Limfosit $\mathrm{T}$ mengalami pematangan di kelenjar thymus yang selanjutnya akan dilepas ke pembuluh darah.

Hasil perhitungan rerata zat gizi pada masing-masing perlakuan didapatkan bahwa kelompok perlakuan diet normal dengan penambahan L-Glutamin dan glukosa unhidrat memiliki tingkat asupan energi tertinggi dibandingan ketiga

perlakuan yang lain. Kelompok perlakuan diet normal dengan penambahan L-Glutamin memiliki tingkat aupan protein yang lebih tinggi dibandingkan kedua perlakuan yang lain. Analisis korelasi antar zat gizi, didapatkan bahwa energi, protein, dan lemak merupakan zat yang memiliki korelasi terhadap peningkatan limfosit dalam darah. Sedangkan karbohidrat tidak memiliki korelasi dibandingkan ketiga zat gizi yang lain. Perlakuan diet normal dengan penambahan LGlutamin+glukosa unhidrat bisa lebih meningkatkan jumlah limfosit dikarenakan jumlah energi dan protein yang tinggi, sedangkan energi dan protein memiliki korelasi terhadap

peningkatan limfosit. Kelompok perlakuan penambahan L-Glutamin dan perlakuan penambahan glukosa unhidrat juga meningkatkan jumlah limfosit

namun tidak setinggi kelompok perlakuan penambahan $\mathrm{L}-$ Glutamin+glukosa unhidrat.

L-Glutamin memegang peranan penting dalam pintalan interorgan dari nitrogen dan karbon dan telah terlihat sebagai energi oksidatif utama untuk pembelahan sel seperti enterosit dan 
limfosit. L-glutamin adalah substrat penting untuk menghasilkan ammonia oleh ginjal, yang merupakan prekursor untuk pembentukan purin dan pirimidin, serta memegang peranan penting dalam regulasi sintesis protein. L-Glutamin terbukti memiliki fungsi yang penting terhadap fungsi berbagai sistem organ, meliputi intestinal, sistem imunitas, dan untuk mempertahankan keseimbangan asam basa. L-glutamine menjadi nutrisi yang esensial selama menderita sakit 8 Sebelumnya L-glutamin belum digunakan sebagai suplemen nutrisi karena beberapa alasan yaitu karena Lglutamin merupakan asam amino non esensial karena tubuh mempunyai kemampuan untuk mensintesa asam amino melalui reaksi sintetase glutamine.

Pada diet normal dan tidak pada kondisi stres/ infeksi sepertinya Lglutamin tidak diperlukan sebagai suplemen pada individu yang sehat.

Namun pada penelitian Neu J (2001) ${ }^{9}$

menyatakan bahwa terputusnya pemberian glutamine akan sangat mengganggu pada bayi yang sangat premature dengan tingkat stress yang tinggi dan sedang dalam pertumbuhan. Pada penelitian pada 68 bayi berat badan lahir rendah yang menerima tambahan Lglutamin pada bulan pertama kehidupan menunjukkan $30 \%$ bayi pada kelompok kontrol mengalami sepsis, dimana hanya $11 \%$ bayi yang menerima glutamine yang mengalami sepsis. Penelitian lainnya pada suplemen glutamine pada jalur parenteral menunjukkan berkurangnya lama pemakaian ventilasi mekanik pada bayi dengan berat badan $<800 \mathrm{~g}$ (Newsholme,2001).

Proliferasi limfosit membutuhkan Lglutamin sebagai bahan baku (Curi R, Pithon Curi\&M.Pires, 2000). Selain LGlutamin, glukosa juga diperlukan dalam proses proliferasi limfosit (Mahan . L.K,

Escott,2003). Sel-T menggunakan glukosa dan glutamin sebagai sumber bahan bakar primer, tetapi zat ketone dan asam lemak bisa digunakan untuk ini meski dalam jumlah kecil. Dari sekian nutrisi ini, glukosa adalah yang penting dan dibutuhkan untuk survival, ukuran, aktivasi sel, dan juga untuk produksi cytokine. Glukosa memberikan energi yang dibutuhkan bagi limfosit dalam cara berikut. (1) Glukosa bisa menjadi substrat primer untuk pembentukan ATP; (2) Glukosa bisa menjadi sumber karbon bagi sintesis nutrisi makro lainnya, seperti asam nukleik dan fosfolipid; dan

(3) Glukosa bisa dimetabolis oleh pathwaypentosefosfatuntuk

menghasilkan NADPH. Untuk pembentukan ATP, glukosa bisa dimetabolis lewat glikolisis atau fosforilasi oksidatif. Glikolisis terjadi dalamsitosol, dimana satu molekul glukosa dipecah menjadi dua molekul piruvat. Reaksi ini adalah proses independen-oksigen (tidak terpengaruh oksigen), dan menghasilkan dua molekul ATP untuk setiap molekul glukosa. Piruvat dikonversi menjadi laktat, dan menghasilkan NAD akseptor elektron lewat NADH. Metabolisme lainnya adalah fosforilasi oksidatif, yaitu proses dependen-oksigen dan ini dilakukan di dalam mitokondria. Proses berisi dua reaksi, yaitu (1) konversi molekul intermediate (asam piruvat dan asam lemak) menjadi koenzim asetil A (coA) dan (2) degradasi asetil coA menjadi $\mathrm{CO}_{2}$ dalam siklus asam trikarboksilik, yang menghasilkan elektron bebas yang dibawa NADH dan flavina denin dinukleotida $\left(\mathrm{FADH}_{2}\right)$, atau ada transfer elektrondari NADH dan $\mathrm{FADH}_{2}$ kerantai transport elektron, yang nantinya membuat proton keluar dari matrik mitokondrial. Potensi elektro kimia kemudian digunakan oleh sinthase ATP untuk membuat ATP, dengan hasil total sebanyak 30 molekul ATP dari setiap molekul glukosa. Karena itu, fosforilasi oksidatif adalah cara efisien untuk menghasilkan ATP dari glukosa, meski beberapa metabolit masih bertahan dalam biosinthesis (KarinchAM et all, 2001) Limfosit resting memiliki kebutuhan energi-rendah, dan mendapatkan banyak ATP-nya dari fosforilasi oksidatif.

Sementara itu, limfosit aktif membutuhkan kenaikan metabolisme yang besar selama aktif. Ini dibutuhkan agar bisa meningkatkan energi yang 
diperlukan untuk menstimulasi pertumbuhan dan proliferasi, dan memproduksi produk protein yang diekspresikan oleh sel immunaktif. Metabolisme glukosa bisa berubah dalam sel-T aktif, dan transisi dari sel-T resting kesel-T aktif akan menyebabkan perpindahan dari metabolisme katabolik metabolisme anabolik. Di perpindahan itu, ATP digunakan untuk menghasilkan molekul makro kompleks dari intermediate yang lebih sederhana.

Limfosit aktif menghasilkan sebagian besar energinya lewat proses up-regulasi glikolisis aerobik. Ini adalah program metabolik dimana sebuah sel tetap mengkonversi piruvat menjadi laktat, meski oksigennya masihcukup. Program metabolik bersama antara limfosit aktif dan sel kanker memiliki relevansi dengan metabolisme limfosit, dan menjadi topik yang bisa diangkat dalam studi metabolisme limfosit. Meski begitu, tidak jelas mengapa sel-T aktif memilih menggunakan glikolisis aerobik untuk pembangkitan energinya, padahal glikolisis membutuhkan kecepatan metabolisme yang tinggi, prekursor biosinthetik juga tersedia banyak, dan produksi ATP dari metabolisme oksidatif selalu tinggi. Namun perlu dicatat bahwa kegagalan meningkatkan metabolisme glukosa selama aktivasi limfosit bisa menghambat pertumbuhan sel. Glutamin bersama dengan glukosa berperan penting dalam proses proliferasi dan replikasi limfosit, berikut ini adalah proses metabolisme sel limfosit dengan glukosa dan glutamin sebagai bahan bakarnya (Newsholme,2001). Glukosa

merupakan pusat dari semua metabolisme. Glukosa adalah bahan bakar universal bagi sel manusia dan merupakan sumber karbon untuk sintesis sebagian besar senyawa lainnya. Semua jenis sel manusia menggunakan glukosa untuk memperoleh energi. Gula lain dalam makanan (terutama fruktosa dan glukosa) diubah menjadi glukosa atau zat antara dalam metabolisme glukosa (Mahan . L.K \&Escott, 2003).

Glukosa memberikan energi yang dibutuhkan bagi limfosit dengan cara glukosa menjadi substrat primer untuk pembentukan ATP; glukosa bisa menjadi sumber karbon bagi sintesis nutrisi makro lainnya, seperti asam nukleik dan fosfolipid; dan glukosa bisa dimetabolis oleh pathway pentosa fosfat untuk menghasilkan NADPH. Pada saat pembentukan ATP, glukosa bisa dimetabolis lewat glikolisis atau fosforilasi oksidatif. Glikolisis terjadi dalam sitosol, dimana satu molekul glukosa dipecah menjadi dua molekul piruvat. Reaksi ini adalah proses independen oksigen (tidak terpengaruh oksigen), dan menghasilkan dua molekul ATP untuk setiap molekul glukosa. Piruvat dikonversi menjadi laktat, dan menghasilkan NAD akseptor elektron lewat NADH. Metabolisme lainnya adalah fosforilasi oksidatif, yaitu proses dependen-oksigen dan proses ini dilakukan di mitokondria (Maclver J,

Nancie, Jacobs R Sarah, 2008)

Limfosit resting memiliki kebutuhan energi rendah, dan mendapatkan banyak ATP-nya dari fosforilasi oksidatif. Limfosit aktif membutuhkan kenaikan metabolisme yang besar selama aktif, ini dibutuhkan agar bisa meningkatkan

energi yang diperlukan untuk menstimulasi pertumbuhan dan proliferasi, dan memproduksi protein yang diekspresikan oleh sel imun aktif. Metabolisme glukosa bisa berubah dalam sel-T aktif, dan transisi dari sel-T resting ke sel-T aktif akan menyebabkan perpindahan dari metabolisme katabolik ke metabolisme anabolik. Limfosit aktif menghasilkan sebagian besar energi lewat proses upregulasi glikolisis

aerobik ${ }^{4}$. Berdasarkan penelitian yang dilakukan oleh Ardawi dan Newsholme, aktivitas L-glutamine meningkat seiring dengan meningkatnya kebutuhan tubuh akan sistem imun (Curi, 2000). Pada

pemberian perlakuan L-Glutamin menunjukkan rerata jumlah limfosit

sebesar $16,13 \pm 3,57 \times 10^{3}$, pada kelompok perlakuan pemberian glukosa unhidrat menunjukkan rerata jumlah limfosit sebesar $16,20 \pm 4,88 \times 10^{3}$, sedangkan pada kelompok perlakuan L-glutamin+glukosa unhidrat menunjukkan rerata tertinggi 
diantara kelompok perlakuan yang lain yaitu $16,98 \pm 4,30 \times 10^{3}$.

Hasil rerata jumlah limfosit menunjukkan bahwa gabungan pemberian L-Glutamin+glukosa unhidrat lebih cepat meningkatkan jumlah limfosit dibandingkan pemberian L-Glutamin dan glukosa unhidrat secara terpisah, hal ini dikarenakan metabolisme limfosit di dalam tubuh membutuhkan dua zat tersebut secara bersamaan. Pada kondisi KEP cadangan glukosa dan glutamin dalam tubuh berkurang, sehingga perlu adanya pemberian glutamin dan glukosa dari luar agar proliferasi limfosit lebih cepat terjadi.

Pemisahan pemberian L-glutamin dan glukosa unhidrat tidak banyak memberikan perubahan yang signifikan pada jumlah limfosit namun agar mendapat hasil maksimal maka gabungan pemberian L-Glutamin dan glukosa unhidrat lebih direkomendasikan. Menurut Newsholme (2001), proliferasi

limfosit membutuhkan L-Glutamin sebagai bahan baku, sedangkan menurut Curi et al (2009) glukosa diperlukan dalam proses proliferasi limfosit, sehingga pemberian gabungan Lglutamin dan glukosa unhidrat lebih baik dibandingkan pemberian L-glutamin dan glukosa unhidrat secara terpisah khususnya pada kondisi KEP

\section{PENUTUP}

Tikus yang diberi penambahan perlakuan L-Glutamin (1,2 gram), glukosa unhidrat (1,2 gram) dan percampuran antara L-glutamin+glukosa unhidrat (2,4 gram) signifikan memiliki jumlah limfosit yang lebih tinggi dibanding kelompok diet normal tanpa perlakuan (kontrol)

\section{DAFTAR RUJUKAN}

Departemen Kesehatan Republik Indonesia. 2000. Pedoman Tata Laksana Kurang Energi Protein Pada Anak Di Rumah Sakit Kabupaten/Kodya. Direktorat Jenderal Bina Gizi Kesehatan Masyarakat : Jakarta
Mezenes, Juscilene da Silva. 2003. Stimulation by food proteins plays a critical role in the maturation of the immune system.

78(online)(http://intimm.oxfordjourn als.org/cgi/content/full/15/3/447). diakses tanggal 10 Julio 2012

Lee WJ, Hawkins RA, Vina JR. Glutamine Transport by The Blood Brain Barrier; PosibleMechanism For Nitrogen Removal. Am. J Physiol Cell 274;1101-1107, 1998

Maclver J, Nancie, Jacobs R Sarah, 2008. Glucose Metabolism in Lymphocytes is A Regulated Process With Significant Effect on Immune Cell Function and Survival. Journal of Leukocyte Biology. Vol. 84.

Migeul P, Beeh KM, Schlaak JF, Buhl R, 2001. Oral supplementation with whey proteins increases plasma gluthatione levels of HIV-Infected patiens. Eur J Clin Invest. 31:171178

Curi et al, 2009. Intracelluler Distribution of Enzymes of The Glutamine Metabolism in Rat Lymphocytes. Biochem. Biophys. Res. Commun. 138:318-322

Irawan, Rudi.2010. Pengaruh Pemberian glutamin pada mikrovili usus tikus malnutrisi. Disertasi. Fakultas Kedokteran. Universitas Airlangga

Parimi PS, Devapatla S, Gruca LL, Amini SB, Hanson RW, Kalhan SC. Effect of Enteral Glutamine or Glysin on Whole Body Nitrogen

Kinetics in very low birth weight infant. Am J Nutr. 2004; 79: 402-9

Newsholme, Philip. Why Is L-Glutamine Metabolism Important to Cells of The Immune System in Health, Postinjury, Surgery of Infection. 2001. J Nutrvol 131 No.9 2515s2522s Curi R, PithonCuri, M.Pires. 2000. Metabolic Fate of Glutamine in Lymphosites, Macrophages and Neutrophils: Braz J Med

Mahan . L.K, Escott. 2003. 11. Krausse's Food Nutrition Diet and Therapy. Philadelphia; W.B. Saunders Co Ed 10 
KarinchAM, Pan M, Lin CM, Strange

Rand, Souba WW. Glutamine
Metabolism in Sepsis and Infection.

J. Nutr. 2001; 131:1535s-2538s. 